\title{
Improving the Efficiency of Dye-Sensitized Solar Cells by Growing Longer ZnO Nanorods on $\mathrm{TiO}_{2}$ Photoanodes
}

\author{
Bao-gai Zhai, Long Yang, and Yuan Ming Huang \\ School of Mathematics and Physics, Changzhou University, Jiangsu 213164, China \\ Correspondence should be addressed to Yuan Ming Huang; dongshanisland@126.com
}

Received 5 March 2017; Accepted 6 June 2017; Published 9 July 2017

Academic Editor: Zafar Iqbal

Copyright (C) 2017 Bao-gai Zhai et al. This is an open access article distributed under the Creative Commons Attribution License, which permits unrestricted use, distribution, and reproduction in any medium, provided the original work is properly cited.

By increasing the temperature of hydrothermal reactions from 70 to $100^{\circ} \mathrm{C}$, vertically aligned $\mathrm{ZnO}$ nanorods were grown on the $\mathrm{TiO}_{2}$ thin film in the photoanode of dye-sensitized solar cells (DSSCs) as the blocking layer to reduce the electron back recombinations at the $\mathrm{TiO}_{2}$ /electrolyte interfaces. The length effects of $\mathrm{ZnO}$ nanorods on the photovoltaic performances of $\mathrm{TiO}_{2}$ based $\mathrm{DSSCs}$ were investigated by means of scanning electron microscope, X-ray diffractometer, photoluminescence spectrophotometer, and the photocurrent-voltage measurement. Under the illumination of $100 \mathrm{~mW} / \mathrm{cm}^{2}$, the power conversion efficiency of DSSC with $\mathrm{ZnO}$ nanorods decorated $\mathrm{TiO}_{2}$ thin film as its photoanode can be increased nearly fourfold from $0.27 \%$ to $1.30 \%$ as the length of $\mathrm{ZnO}$ nanorods increases from 300 to $1600 \mathrm{~nm}$. The enhanced efficiency of DSSC with $\mathrm{ZnO}$ nanorods decorated $\mathrm{TiO}_{2}$ thin film as the photoanode can be attributed to the larger surface area and the lower defect density in longer ZnO nanorods, which are in favor of more dye adsorption and more efficient transport in the photoanode.

\section{Introduction}

$\mathrm{TiO}_{2}$ based dye-sensitized solar cells (DSSCs) have been recognized as the promising candidates for next-generation solar cells due to their low production cost, low environmental impact, and relatively high power conversion efficiency [1-5]. A typical DSSC consists of a photoanode containing the wide bandgap semiconductor $\mathrm{TiO}_{2}$, a Pt counter electrode, and a liquid electrolyte containing the $\mathrm{I}^{-} / \mathrm{I}_{3}{ }^{-}$redox couple. Under illumination, the dye molecules adsorbed on $\mathrm{TiO}_{2}$ are excited to their lowest unoccupied molecule orbitals with the result of released photoelectrons, and then the released photoelectrons are injected into the wide bandgap semiconductor $\mathrm{TiO}_{2}$ [6-9]. Consequently the interface between $\mathrm{TiO}_{2}$ and the electrolyte becomes critically important in improving the power conversion efficiency of the $\mathrm{TiO}_{2}$ based DSSCs [6-11]. It is well recognized that a further increase in the power conversion efficiency has been limited by energy loss due to the recombination of electrons in the photoanode with the oxidized dye molecules or with the electron-accepting species in the electrolyte [10-13]. In order to minimize the electron back transfer from $\mathrm{TiO}_{2}$ to the redox electrolyte, vertically aligned $\mathrm{ZnO}$ nanorods are often applied to DSSCs as the blocking layer since they can form an energy barrier at the electrolyte $/ \mathrm{TiO}_{2}$ interface in addition to providing large surface area for dye adsorption and direct pathway for efficient electron transport from the electrolyte to the photoanode $[3,4,6,7]$. In particular, Wijeratnea and Bandara recently reported that the electron transport and recombination properties of $\mathrm{ZnO}$-based DSSCs depended on the aspect ratio of randomly dispersed $\mathrm{ZnO}$ nanorods in the photoanodes [14]. Therefore, the length of vertically aligned $\mathrm{ZnO}$ nanorods in the blocking layer can inevitably generate significant impacts on the photovoltaic performances of $\mathrm{TiO}_{2}$ based DSSCs. However, the length effects of the vertically aligned $\mathrm{ZnO}$ nanorods on the power conversion efficiency are not explored for DSSC with $\mathrm{ZnO}$ nanorods decorated $\mathrm{TiO}_{2}$ thin film as its photoanode. For brevity, the photoanode with the structure of $\mathrm{ZnO}$ nanorods decorated $\mathrm{TiO}_{2}$ thin film is shortened as $\mathrm{ZnO}-\mathrm{TiO}_{2}$ photoanode.

In the present work, we investigated the length effects of vertically aligned $\mathrm{ZnO}$ nanorods in the $\mathrm{ZnO}-\mathrm{TiO}_{2}$ photoanode on the photovoltaic performance of the DSSC. Vertically aligned $\mathrm{ZnO}$ nanorods with tunable lengths ranging from 300 to $1600 \mathrm{~nm}$ and diameters of about $75 \mathrm{~nm}$ were grown on 600 -nm thick $\mathrm{TiO}_{2}$ thin films by varying the temperature of 
hydrothermal reactions from 70 to $100^{\circ} \mathrm{C}$. The morphologies, crystal structures, and optical properties of vertically aligned $\mathrm{ZnO}$ nanorods were characterized by means of scanning electron microscope (SEM), X-ray diffractometer (XRD), and photoluminescence (PL) spectrophotometer. Our photocurrent-voltage $(J-V)$ measurements under the light illumination of $100 \mathrm{~mW} / \mathrm{cm}^{2}$ demonstrated that the power conversion efficiency of the DSSC with the $\mathrm{ZnO}-\mathrm{TiO}_{2}$ photoanode was enhanced nearly fourfold from $0.27 \%$ to $1.30 \%$ as the length of $\mathrm{ZnO}$ nanorods increased from 300 to $1600 \mathrm{~nm}$.

\section{Materials and Methods}

2.1. Materials. All of the chemicals used in this study were of analytical grade and were purchased from local chemical suppliers unless mentioned otherwise $[3,6]$. Fluorine-doped tin oxide conductive glass (FTO, sheet resistance of about $14 \Omega \mathrm{cm}^{-2}$, thickness $2.2 \mathrm{~mm}$ ) was used as the electrode substrate. Di-tetrabutylammonium cis-bis (isothiocyanato) bis (2,2' -bipyridyl-4,4'-dicarboxylato) ruthenium (II) (N719) was used as the dye in our DSSCs. The ethanol solution of chloroplatinic acid hexahydrate was used to prepare the counter electrodes.

2.2. $\mathrm{TiO}_{2}$ Thin Films. The $\mathrm{TiO}_{2}$ thin film in the photoanode consisted of a compact $\mathrm{TiO}_{2}$ layer $(50 \mathrm{~nm})$ and a porous $\mathrm{TiO}_{2}$ layer $(550 \mathrm{~nm})$ on FTO glass substrate. The compact $\mathrm{TiO}_{2}$ layer was formed on the FTO glass substrate after having been immersed into an aqueous solution of $\mathrm{TiCl}_{4}(0.04 \mathrm{M})$ at $70^{\circ} \mathrm{C}$ for $30 \mathrm{~min}$ and subsequently sintered at $450^{\circ} \mathrm{C}$ for $30 \mathrm{~min}$. The porous $\mathrm{TiO}_{2}$ layer was deposited on the compact $\mathrm{TiO}_{2}$ layer by dipping the FTO substrates into $\mathrm{TiO}_{2}$ sol for $10 \mathrm{~min}$ and then calcinating at $450^{\circ} \mathrm{C}$ for $2 \mathrm{~h}$ (5 cycles). The $\mathrm{TiO}_{2}$ sol was a mixture of tetrabutyl titanate $(4 \mathrm{~mL})$, diethanolamine $(2 \mathrm{~mL})$, deionized water $(1.5 \mathrm{~mL})$, acetate acid $(1.2 \mathrm{~mL})$, polyethylene glycol (PEG-2000, $0.045 \mathrm{~g})$, and butyl alcohol $(60 \mathrm{~mL})$ that had been aged for $16 \mathrm{~h}$. Details on preparing the $\mathrm{TiO}_{2}$ photoanodes were described in our recent work $[3,4,6]$.

2.3. Decoration of the $\mathrm{TiO}_{2}$ Thin Film with $\mathrm{ZnO}$ Nanorods. $\mathrm{ZnO}$ nanorods were grown vertically onto the $\mathrm{TiO}_{2}$ photoanode via the hydrothermal route: (i) $\mathrm{ZnO}$ seeding solution was prepared by dissolving zinc acetate dehydrate $(6.6 \mathrm{~g})$ and ethanolamine $(1.8 \mathrm{~mL})$ into ethanol $(60 \mathrm{~mL})$; (ii) one $\mathrm{ZnO}$ seed layer was formed on the $\mathrm{TiO}_{2}$ thin film by dipping the photoanode into the $\mathrm{ZnO}$ seeding solution for about $1 \mathrm{~min}$ and then drying at $300^{\circ} \mathrm{C}$ for $10 \mathrm{~min}$ ( 3 cycles); (iii) the $\mathrm{ZnO}$ coated $\mathrm{TiO}_{2}$ thin film was loaded into a Teflon-lined stainless steel autoclave for reaction at a specific temperature for $5 \mathrm{~h}$. The solution in the autoclave was the aqueous solution of zinc nitrate $(0.05 \mathrm{M})$ and hexamethylenetetramine $(0.05 \mathrm{M})$. Four kinds of $\mathrm{ZnO}$ nanorods with different lengths were obtained by setting the temperatures in the autoclave at $70,80,90$, and $100^{\circ} \mathrm{C}$, respectively.

2.4. DSSC Assembling. The $\mathrm{ZnO}-\mathrm{TiO}_{2}$ photoanodes were dye-sensitized by immersing them into the ethanol solution of the N719 dye $(0.4 \mathrm{mM})$ for $20 \mathrm{~min}$. Each dye-sensitized photoanode was assembled with a Pt counter electrode into a sandwiched structure with a $25-\mu \mathrm{m}$ thick sealing spacer between them. The Pt counter electrode was prepared by immersing one piece of cleaned FTO substrate in an ethanol solution of $\mathrm{H}_{2} \mathrm{PtCl}_{6}(4 \mathrm{mM})$ and then annealing it at $450^{\circ} \mathrm{C}$ for $2 \mathrm{~h}$. The free space in the sandwiched structure was filled with a redox liquid electrolyte. The electrolyte was the acetonitrile solution of $\mathrm{KI}(0.5 \mathrm{M})$ and $\mathrm{I}_{2}(0.05 \mathrm{M})$.

2.5. Characterizations. A SEM (Hitachi S-4800, Japan) was employed to characterize the morphologies of the $\mathrm{ZnO}-\mathrm{TiO}_{2}$ photoanodes. The crystal structures of the $\mathrm{ZnO}$ nanorods were analyzed by XRD (D/max 2500 PC, Rigaku, Japan) with a copper target radiation. The PL spectra of samples were recorded with a spectrophotometer. The $325 \mathrm{~nm}$ laser line from a helium-cadmium laser was employed as excitation source for the PL measurement. The output power of ultraviolet laser was about $12 \mathrm{~mW}$. For the $J-V$ measurement of the DSSCs, an AM 1.5 solar simulator with a $500 \mathrm{~W}$ xenon lamp was employed to illuminate the DSSC; the incident light power on the solar cells was calibrated to $100 \mathrm{~mW} / \mathrm{cm}^{2}$. The active area of each solar cell was $0.25 \mathrm{~cm}^{2}$. Other parameters on the instrumentation were available elsewhere $[3,4,6$, 15-17]. The nanostructures of the $\mathrm{ZnO}-\mathrm{TiO}_{2}$ photoanode were characterized with a transmission electron microscope (TEM) (JEOL JEM-2100, Japan Electronics Corp) which was operated at $200 \mathrm{kV}$.

\section{Results and Discussion}

Figure 1 shows the top-view and cross-sectional SEM micrographs of the prepared $\mathrm{ZnO}-\mathrm{TiO}_{2}$ photoanodes. The panels (A)-(D) in Figure 1(a) represent the cross-sectional SEM micrographs of the $\mathrm{ZnO}-\mathrm{TiO}_{2}$ photoanodes grown at (A) $70^{\circ} \mathrm{C}$, (B) $80^{\circ} \mathrm{C}$, (C) $90^{\circ} \mathrm{C}$, and (D) $100^{\circ} \mathrm{C}$ for $5 \mathrm{~h}$. It can be seen clearly that the $\mathrm{ZnO}$ nanorods were vertically grown onto the $\mathrm{TiO}_{2}$ thin films. The average lengths of the $\mathrm{ZnO}$ nanorods were $300,800,1400$, and $1600 \mathrm{~nm}$ when the growth temperatures were $70,80,90$, and $100^{\circ} \mathrm{C}$, respectively. The panels $(\mathrm{E})-(\mathrm{H})$ in Figure 1(b) display the top-view SEM micrographs of the $\mathrm{ZnO}-\mathrm{TiO}_{2}$ photoanodes grown at (A) $70^{\circ} \mathrm{C}$, (B) $80^{\circ} \mathrm{C}$, (C) $90^{\circ} \mathrm{C}$, and (D) $100^{\circ} \mathrm{C}$ for $5 \mathrm{~h}$, respectively. These top-view SEM micrographs illustrate that the vertically aligned $\mathrm{ZnO}$ nanorods are densely populated on the $\mathrm{TiO}_{2}$ thin films. The average diameters of $\mathrm{ZnO}$ nanorods are about $75 \mathrm{~nm}$, regardless of the differences in the growth temperatures. Thus, the aspect ratios of the $\mathrm{ZnO}$ nanorods are 4.0,10.7, 18.7, and 21.3 when the growth temperatures were $70,80,90$, and $100^{\circ} \mathrm{C}$, respectively. Moreover, the thickness of the $\mathrm{TiO}_{2}$ layer, which is around $600 \mathrm{~nm}$, can be estimated from the SEM micrographs in Figure 1. Further TEM and selected area electron diffraction analyses reveal that these $\mathrm{ZnO}$ nanorods are single crystalline [16, 17]. Consequently, the data in Figure 1 have demonstrated that vertically aligned $\mathrm{ZnO}$ nanorods with lengths varying from 300 to $1600 \mathrm{~nm}$ are onto the $\mathrm{TiO}_{2}$ thin films as the hydrothermal growth temperature increases from 70 to $100^{\circ} \mathrm{C}$. The larger surface area provided by longer $\mathrm{ZnO}$ nanorods is helpful for more dye adsorption. 


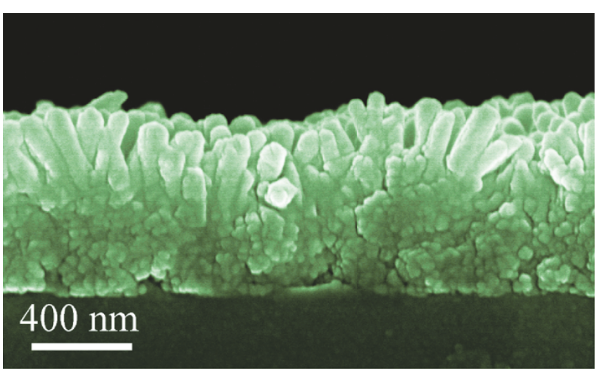

(A)

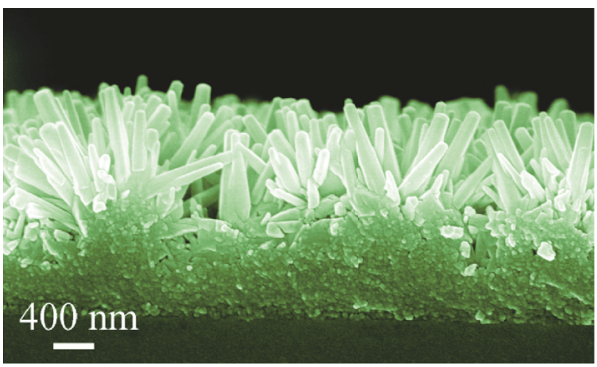

(B)

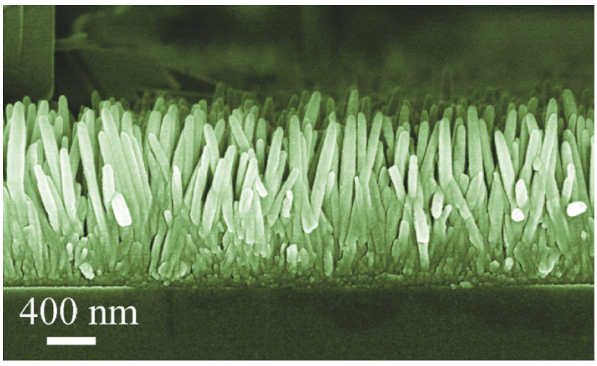

(C)

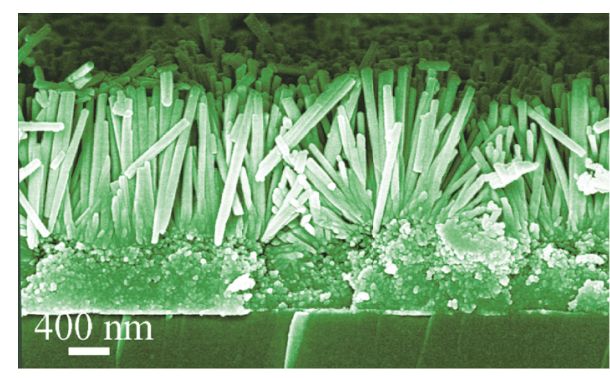

(D)

(a)

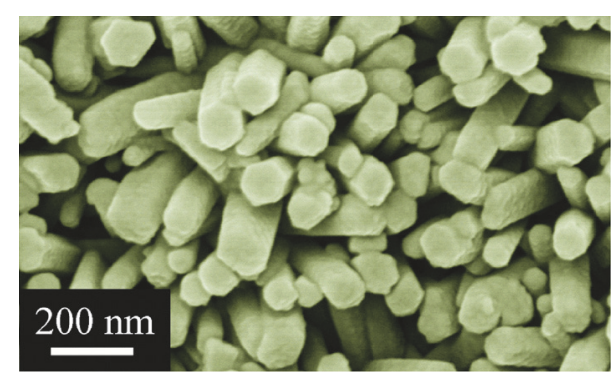

(E)

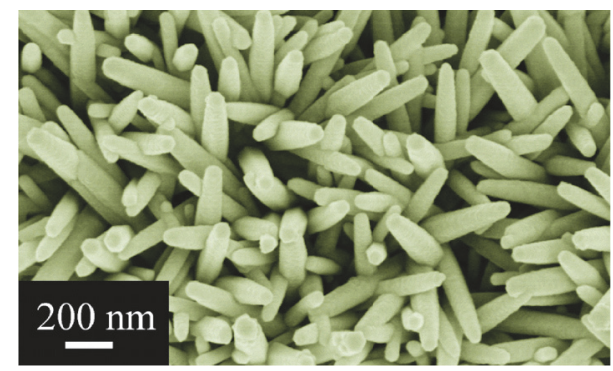

(F)

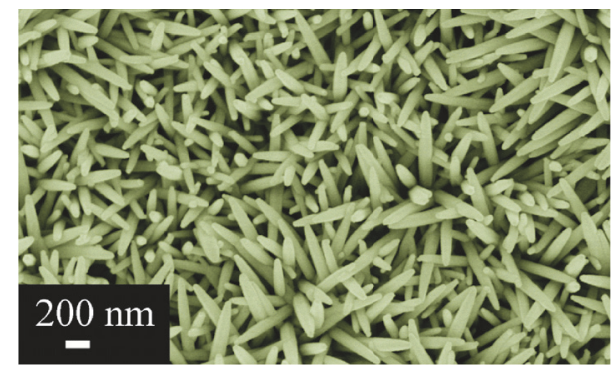

(G)

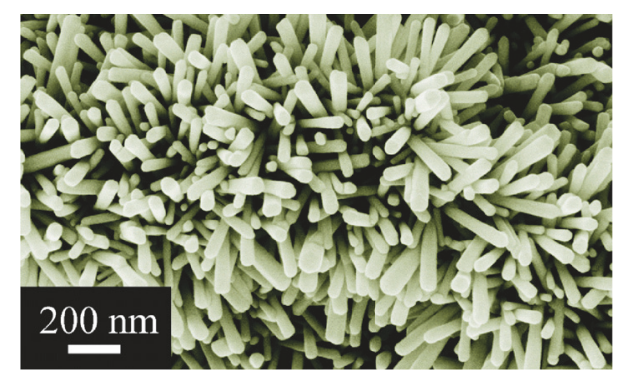

(H)

(b)

Figure 1: (a) Cross-sectional SEM micrographs of the $\mathrm{ZnO}-\mathrm{TiO}_{2}$ photoanodes grown at (A) $70^{\circ} \mathrm{C}$, (B) $80^{\circ} \mathrm{C}$, (C) $90^{\circ} \mathrm{C}$, and (D) $100^{\circ} \mathrm{C}$. (b) Top-view SEM micrographs of the $\mathrm{ZnO}-\mathrm{TiO}_{2}$ photoanodes grown at $(\mathrm{E}) 70^{\circ} \mathrm{C},(\mathrm{F}) 80^{\circ} \mathrm{C},(\mathrm{G}) 90^{\circ} \mathrm{C}$, and $(\mathrm{H}) 100^{\circ} \mathrm{C}$.

Figure 2 shows the XRD spectra of the $\mathrm{ZnO}-\mathrm{TiO}_{2}$ photoanodes grown at (a) $70^{\circ} \mathrm{C}$, (b) $80^{\circ} \mathrm{C}$, (c) $90^{\circ} \mathrm{C}$, and (d) $100^{\circ} \mathrm{C}$, respectively. The diffraction peaks at $2 \theta=31.6,34.2$, $36.0,47.4,56.5,62.8$, and 67.8 in each XRD spectrum can be assigned to the reflections from the (100), (002), (101), (102), (110), (103), and (112) planes of the hexagonal $\mathrm{ZnO}$, whose standard lattice constants are $a=0.325 \mathrm{~nm}$ and $c=0.521 \mathrm{~nm}$, according to the Joint Committee on Powder Diffraction Standard (JCPDF number 36-1451) [3, 4, 6, 17]. It is noted that the (002) peak at $2 \theta=34.2^{\circ}$ becomes much more dominant in intensity as the growth temperature gets higher, indicating the enhanced directional order of the $\mathrm{ZnO}$ nanorods formed at higher temperature. According to the diffraction equations, the lattice constants $a$ and $c$ can be calculated for the $\mathrm{ZnO}$ nanorods grown at different temperatures. Our calculated lattice constants, which are very close to those of wurtzite $\mathrm{ZnO}$, are summarized in Table 1. Additionally, it is well established that the degree of orientation of $\mathrm{ZnO}$ nanocrystals can be evaluated by the texture coefficients (TCs), which is defined by the following equation [22]:

$$
\mathrm{TC}_{(h k l)}=\frac{I_{(h k l)} / I_{(h k l)}^{o}}{(1 / N) \sum I_{(h k l)} / I_{(h k l)}^{o}},
$$


TABLE 1: Parameters of $\mathrm{ZnO}$ nanorods and the photovoltaic parameters of $\mathrm{ZnO}$ nanorods decorated DSSCs.

\begin{tabular}{lcccccrrr}
\hline $\begin{array}{l}\text { Growth temp } \\
\left({ }^{\circ} \mathrm{C}\right)\end{array}$ & $\begin{array}{c}\text { Length } \\
(\mathrm{nm})\end{array}$ & $\begin{array}{c}\text { Diameter } \\
(\mathrm{nm})\end{array}$ & $\begin{array}{c}a \\
(\mathrm{~nm})\end{array}$ & $\begin{array}{c}c \\
(\mathrm{~nm})\end{array}$ & $\begin{array}{c}J_{\text {sc }} \\
\left(\mathrm{mA} / \mathrm{cm}^{2}\right)\end{array}$ & $\begin{array}{c}V_{\text {oc }} \\
(\mathrm{V})\end{array}$ & $\begin{array}{c}\eta \\
(\%)\end{array}$ \\
\hline No decoration & $\mathrm{na}$ & $\mathrm{na}$ & $\mathrm{na}$ & $\mathrm{na}$ & 0.37 & 0.66 & 0.15 & 0.614 \\
70 & 300 & 75 & 0.327 & 0.523 & 0.92 & 0.61 & 0.27 & 0.481 \\
80 & 1000 & 75 & 0.326 & 0.522 & 1.60 & 0.59 & 0.56 & 0.594 \\
90 & 1400 & 75 & 0.327 & 0.523 & 2.70 & 0.56 & 0.84 & 0.555 \\
100 & 1600 & 75 & 0.326 & 0.522 & 4.23 & 0.55 & 1.30 & 0.559 \\
\hline
\end{tabular}

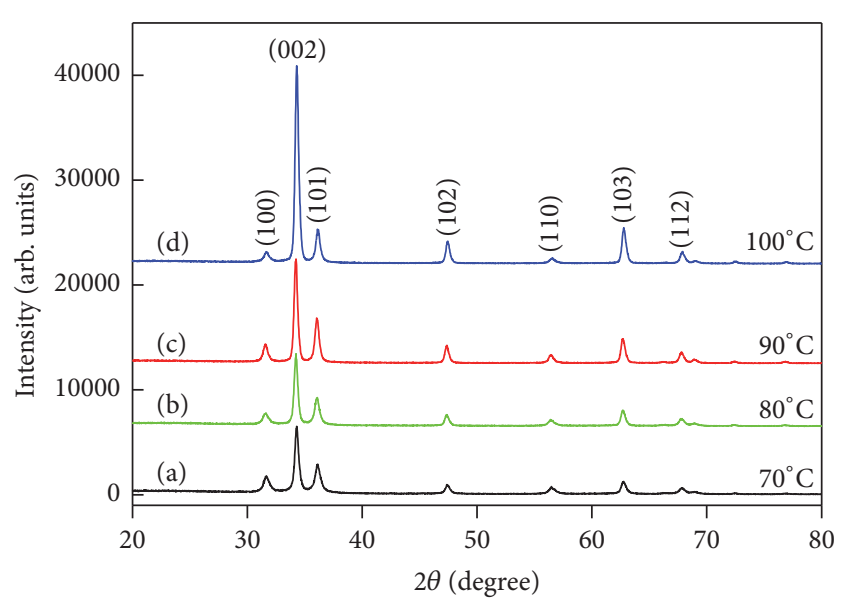

FIGURE 2: XRD spectra of the $\mathrm{ZnO}-\mathrm{TiO}_{2}$ photoanodes grown at (a) $70^{\circ} \mathrm{C}$; (b) $80^{\circ} \mathrm{C}$; (c) $90^{\circ} \mathrm{C}$; and (d) $100^{\circ} \mathrm{C}$.

where $N$ is the number of diffraction peaks, $I_{(h k l)}$ is the experimentally measured intensity of the diffraction peak $(h k l)$, and $I_{(h k l)}^{o}$ is the recorded intensity of the $(h k l)$ diffraction peak according to the JCPDS 036-1451 card. According to (1), the TCs for the (002) orientations were calculated to be $3.30,3.453,3.585$, and 4.20 for the $\mathrm{ZnO}$ nanorods grown at $70,80,90$, and $100^{\circ} \mathrm{C}$, respectively. The higher $\mathrm{TC}_{(002)}$ value shows that the $\mathrm{ZnO}$ nanorods are more perfectly aligned with their $c$-axis perpendicular to the substrate. Therefore, the data in Figure 2 has given further evidence on the formation of hexagonal $\mathrm{ZnO}$ nanorods and their perpendicular alignment on the substrates.

Figure 3 illustrates the room temperature PL spectra of the $\mathrm{ZnO}-\mathrm{TiO}_{2}$ photoanodes grown at (a) $70^{\circ} \mathrm{C}$, (b) $80^{\circ} \mathrm{C}$, (c) $90^{\circ} \mathrm{C}$, and (d) $100^{\circ} \mathrm{C}$, respectively. It is obvious that each PL spectrum in Figure 3 consists of an ultraviolet PL band with its peak at about $378 \mathrm{~nm}$ and a green PL band with its peak at about $540 \mathrm{~nm}$. The ultraviolet PL band is generally attributed to the band-edge recombination of excitons whereas the green $\mathrm{PL}$ band is produced by defects in $\mathrm{ZnO}$ [15-17, 22-25]. Therefore, the higher fraction of the green PL intensity in the PL spectrum suggests the presence of higher defect density in $\mathrm{ZnO}$ nanorods. On the basis of the PL data in Figure 3, the fractions of the green PL intensity in the PL spectra are derived to be $0.9768,0.9061,0.8958$, and 0.8479 for the PL curves (a)-(d), respectively. So, lower defect density is present in $\mathrm{ZnO}$ nanorods when growth temperature gets higher. Combined to the results in Figure 2, it is obvious that the

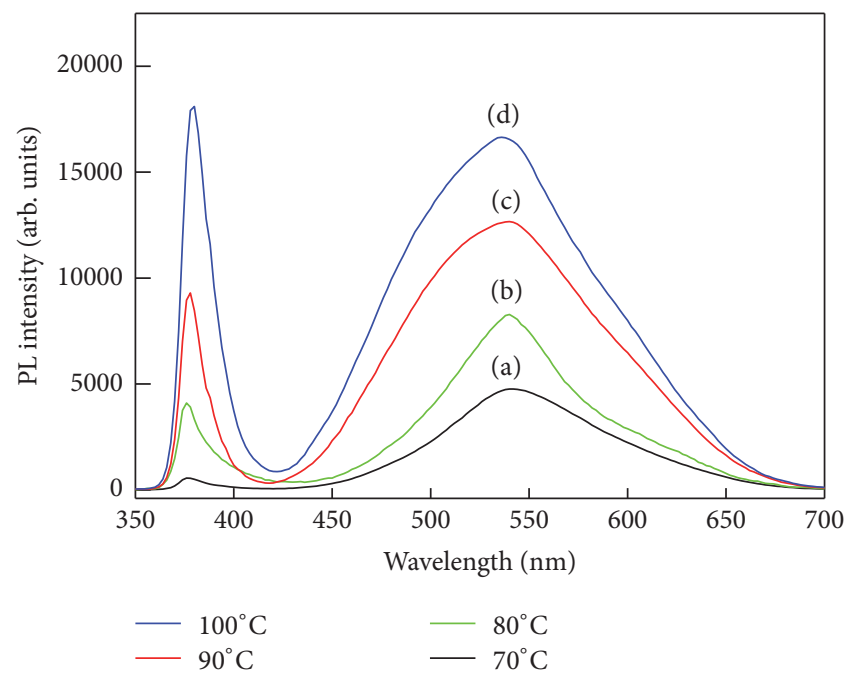

Figure 3: PL spectra of $\mathrm{ZnO}-\mathrm{TiO}_{2}$ photoanodes grown at (a) $70^{\circ} \mathrm{C}$; (b) $80^{\circ} \mathrm{C}$; (c) $90^{\circ} \mathrm{C}$; and (d) $100^{\circ} \mathrm{C}$.

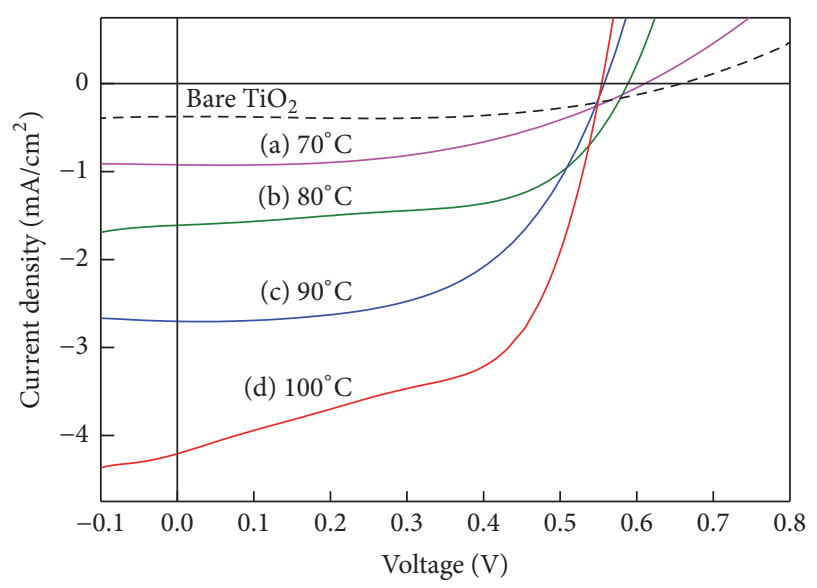

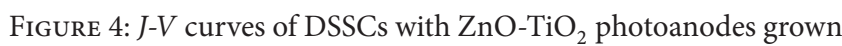
at different temperatures: (a) $70^{\circ} \mathrm{C}$; (b) $80^{\circ} \mathrm{C}$; (c) $90^{\circ} \mathrm{C}$; and (d) $100^{\circ} \mathrm{C}$.

lower defect density in longer $\mathrm{ZnO}$ nanorods is good for more efficient electron transport in the nanorods.

Figure 4 presents the $J-V$ curves of DSSCs with the $\mathrm{ZnO}-\mathrm{TiO}_{2}$ photoanodes grown at different temperatures, (a) $70^{\circ} \mathrm{C}$, (b) $80^{\circ} \mathrm{C}$, (c) $90^{\circ} \mathrm{C}$, and (d) $100^{\circ} \mathrm{C}$. The $J-V$ curve of the DSSC without the decoration of $\mathrm{ZnO}$ nanorods is shown in Figure 4 as a reference (dashed line). All the $J$ $V$ curves were measured under the illumination of one sun 
$\left(100 \mathrm{~mW} / \mathrm{cm}^{2}\right)$. The photovoltaic performance parameters of the DSSCs, that is, the short-circuit current density $\left(J_{S C}\right)$, open-circuit voltage $\left(V_{\mathrm{OC}}\right)$, filling factor $(\mathrm{FF})$, and power conversion efficiency $(\eta)$, are summarized in Table 1. It can be seen in both Figure 4 and Table 1 that the length of vertically aligned $\mathrm{ZnO}$ nanorods generates a significant effect on the photovoltaic performance of the DSSCs. As the length of the $\mathrm{ZnO}$ nanorods increases from 300 to $1600 \mathrm{~nm}$, the $J_{\mathrm{SC}}$ of the DSSCs increases from 0.92 to $4.23 \mathrm{~mA} / \mathrm{cm}^{2}$, in the meanwhile the $V_{\mathrm{OC}}$ of the DSSCs decreases slightly from 0.61 to $0.55 \mathrm{~V}$, yielding the overall efficiency of the DSSCs of $0.27,0.56,0.84$, and $1.30 \%$, respectively. In contrast, those parameters for the DSSC without $\mathrm{ZnO}$ decoration are $0.37 \mathrm{~mA} / \mathrm{cm}^{2}, 0.66 \mathrm{~V}$, and $0.15 \%$, respectively. The improved photovoltaic performance of DSSCs can be attributed to the following facts: (i) an energy barrier is formed at the $\mathrm{TiO}_{2}$ /electrolyte interface to reduce the electron back recombination $[3,4,6-10]$; (ii) the longer $\mathrm{ZnO}$ nanorods provide larger surface area for more dye adsorption; and (iii) the lower defect density in longer $\mathrm{ZnO}$ nanorods favors more efficient electron transport in the nanorods. More specifically, the enhancement in $J_{\mathrm{SC}}$ can be attributed to the larger surface area and the lower defect density in longer $\mathrm{ZnO}$ nanorods whilst the slight decrease in $V_{\mathrm{OC}}$ can be caused by the larger serial resistance in the longer $\mathrm{ZnO}$ nanorods. Therefore, the data in Figure 4 have demonstrated that growing longer $\mathrm{ZnO}$ nanorods on $\mathrm{TiO}_{2}$ thin films can effectively enhance the efficiency of the DSSCs. The presented data in Figure 4 were reproduced in four batches of solar cells; each batch consisted of one DSSC without the decoration of $\mathrm{ZnO}$ nanorods and four DSSCs with the $\mathrm{ZnO}-\mathrm{TiO}_{2}$ photoanodes. The statistical derivations of the efficiency were found to be within $\pm 7 \%$ for the samples.

The solar power conversion efficiencies of DSSCs with conventional $\mathrm{TiO}_{2}$ photoanodes were routinely reported to be more than $5 \%$ even without any scattering layer or blocking layer $[1,2,5]$. It is well established that the solar power conversion efficiency of conventional $\mathrm{TiO}_{2}$ based DSSCs heavily depends on the thickness of the $\mathrm{TiO}_{2}$ photoanode $[26,27]$, and that very thick $\mathrm{TiO}_{2}$ photoanodes $(10-20 \mu \mathrm{m})$ are routinely employed to achieve high efficiency up to $12 \%$. For example, Wu et al. reported the efficiency of $8.19 \%$ when the $\mathrm{TiO}_{2}$ film was $20 \mu \mathrm{m}$ thick [26]. As shown in Figure 1, the thickness of our sol-gel derived $\mathrm{TiO}_{2}$ layer is only about $0.6 \mu \mathrm{m}$. That is the reason why our $\mathrm{TiO}_{2}$ based DSSC has a very low efficiency of $0.15 \%$. Since it is hard to make thick $\mathrm{TiO}_{2}$ films via the sol-gel process, we employed the doctor blade technique to prepare $15 \mu \mathrm{m}$ thick $\mathrm{TiO}_{2}$ photoanodes for the DSSCs. Our measured efficiency of the thick $\mathrm{TiO}_{2}$ based DSSCs without the decoration of $\mathrm{ZnO}$ nanorods was $4.3 \%$ whilst the efficiency of the thick $\mathrm{TiO}_{2}$ based DSSCs with the decoration of vertically aligned $\mathrm{ZnO}$ nanorods $(1 \mu \mathrm{m}$ thick) reached up to $9.8 \%$. Compared to the thick $\mathrm{TiO}_{2}$ films made with the doctor blade technique, the thin $\mathrm{TiO}_{2}$ films grown via the sol-gel process exhibit the advantages of uniform thickness of the film, no cracks in the films, and very good reproducibility in the solar power conversion efficiency for the $\mathrm{TiO}_{2}$ based DSSCs. In order to derive a reliable relationship between the efficiency of the DSSCs and the length of $\mathrm{ZnO}$ nanorods, we have chosen sol-gel derived thin $\mathrm{TiO}_{2}$ films as the first layer in the photoanodes of our DSSCs. Surely there are several other major areas for improvement before we can have a comprehensive understanding on $\mathrm{ZnO}$ nanorods decorated DSSCs.

Both the morphology and the size of the nanostructured crystallites are important factors to influence the solar power conversion efficiency of DSSC with the $\mathrm{ZnO}-\mathrm{TiO}_{2}$ photoanode. We derived the $\mathrm{ZnO}$ nanorods and the $\mathrm{TiO}_{2}$ nanoparticles from the photoanode by scratching the photoanode with a blade plus ultrasonicating in water for $30 \mathrm{~min}$. Figure 5(a) displays the high-resolution TEM micrograph of a piece of $\mathrm{TiO}_{2}$ thin film derived from the $\mathrm{ZnO}-\mathrm{TiO}_{2}$ photoanode. It can be seen clearly in Figure 5(a) that the piece of $\mathrm{TiO}_{2}$ thin film consists of numerous $\mathrm{TiO}_{2}$ nanoparticles whose sizes are in the range of 3-10 $\mathrm{nm}$. The inset in Figure 5(a) represents the crystal lattice of one $\mathrm{TiO}_{2}$ nanoparticle. As shown by the inset, the lattice spacing of (101) crystallographic plane is around $0.352 \mathrm{~nm}$. Figure 5(b) shows the selected area electron diffraction pattern of $\mathrm{TiO}_{2}$ nanoparticles derived from the $\mathrm{ZnO}-\mathrm{TiO}_{2}$ photoanode. The bright spots in Figure 5(b) give evidence on the crystalline nature of the $\mathrm{TiO}_{2}$ nanoparticles in the photoanode. Figure 5(c) depicts the low resolution TEM micrograph of $\mathrm{ZnO}$ nanorods derived from $\mathrm{ZnO}-\mathrm{TiO}_{2}$ photoanode. It is observed in Figure 5(c) that both long and short $\mathrm{ZnO}$ nanorods are present. The lengths of the long $\mathrm{ZnO}$ nanorods are around $300 \mathrm{~nm}$ with their diameters of around $20 \mathrm{~nm}$. The short $\mathrm{ZnO}$ nanorods in Figure 5(c) are believed to be the broken fragments of long $\mathrm{ZnO}$ nanorods when they are scratched off the photoanode.

The quality of the interface between $\mathrm{ZnO}$ nanorods and the $\mathrm{TiO}_{2}$ nanoparticles is another critical parameter to influence the solar power conversion efficiency of DSSC with the $\mathrm{ZnO}-\mathrm{TiO}_{2}$ photoanode. Hence it would be better to display the cross-sectional view of TEM image of the interface between $\mathrm{ZnO}$ and $\mathrm{TiO}_{2}$. However, it is rather difficult to prepare high quality samples for high-resolution TEM characterization since ultrasonication introduced shock wave breaks $\mathrm{TiO}_{2}$ nanoparticles away from $\mathrm{ZnO}$ nanorods. As a compensation, we characterized the $\mathrm{ZnO}-\mathrm{TiO}_{2}$ interface with SEM. Figure 6 shows the cross-sectional SEM micrographs of the $\mathrm{ZnO}-\mathrm{TiO}_{2}$ interface in the photoanode: (a) the $\mathrm{ZnO}$ $\mathrm{TiO}_{2}$ interface whose $\mathrm{ZnO}$ nanorods were grown at $70^{\circ} \mathrm{C}$; (b) an enlarged section of the $\mathrm{ZnO}-\mathrm{TiO}_{2}$ interface whose $\mathrm{ZnO}$ nanorods were grown at $70^{\circ} \mathrm{C}$; and (c) free-standing $\mathrm{ZnO}$ $\mathrm{TiO}_{2}$ interface whose $\mathrm{ZnO}$ nanorods were grown at $80^{\circ} \mathrm{C}$. It is clear that $\mathrm{ZnO}$ nanorods are grown vertically on the top surface of the $\mathrm{TiO}_{2}$ thin film, no matter the $\mathrm{TiO}_{2}$ thin film is smooth or rough.

As stated in the Introduction, the length effects of vertically aligned $\mathrm{ZnO}$ nanorods on the power conversion efficiency of DSSC with the $\mathrm{ZnO}-\mathrm{TiO}_{2}$ photoanode were not reported in the literature. Although Wijeratne and Bandara studied the aspect ratio effect of $\mathrm{ZnO}$ nanorods on the electron transport and recombination properties of $\mathrm{ZnO}$-based 


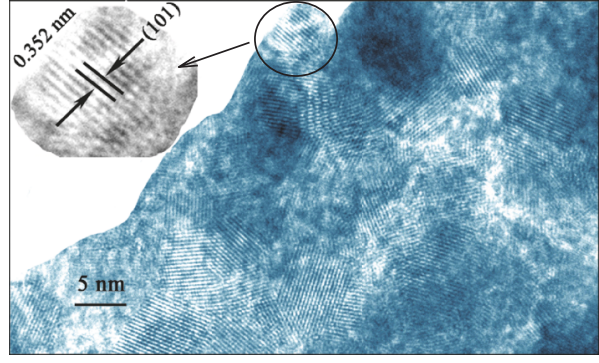

(a)

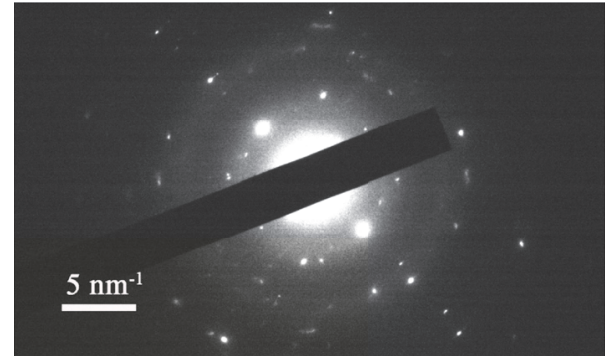

(b)

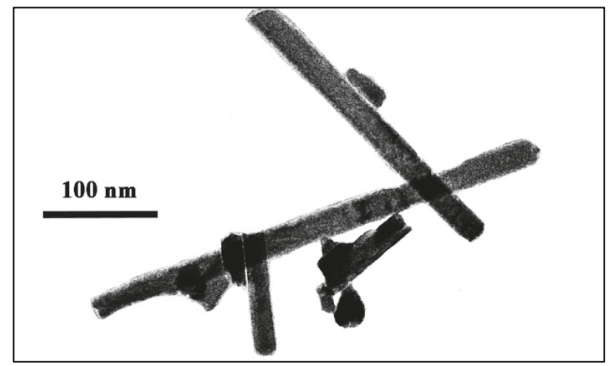

(c)

Figure 5: (a) High-resolution TEM micrograph of $\mathrm{TiO}_{2}$ derived from the $\mathrm{ZnO}-\mathrm{TiO}_{2}$ photoanode. (b) Selected area electron diffraction pattern of $\mathrm{TiO}_{2}$ nanoparticles derived from the $\mathrm{ZnO}-\mathrm{TiO}_{2}$ photoanode. (c) Low resolution TEM micrograph of $\mathrm{ZnO}$ nanorods derived from the $\mathrm{ZnO}-\mathrm{TiO}_{2}$ photoanode.

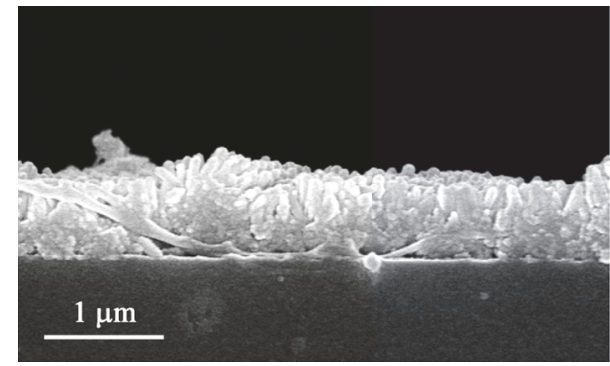

(a)

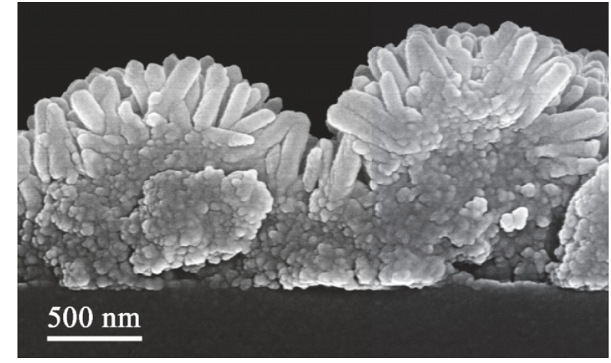

(b)

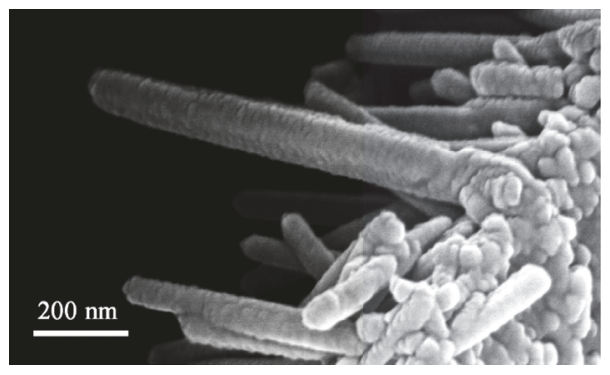

(c)

FIGURE 6: Cross-sectional SEM micrographs of the $\mathrm{ZnO}_{-} \mathrm{TiO}_{2}$ interface in the photoanode: (a) the $\mathrm{ZnO}-\mathrm{TiO}_{2}$ interface whose $\mathrm{ZnO}$ nanorods were grown at $70^{\circ} \mathrm{C}$; (b) an enlarged section of the $\mathrm{ZnO}-\mathrm{TiO}_{2}$ interface whose $\mathrm{ZnO}$ nanorods were grown at $70^{\circ} \mathrm{C}$; and (c) free-standing $\mathrm{ZnO}-\mathrm{TiO}_{2}$ interface whose $\mathrm{ZnO}$ nanorods were grown at $80^{\circ} \mathrm{C}$.

DSSCs, their photoanodes were composed of $\mathrm{ZnO}$ nanorods only [14]. Table 2 lists the photovoltaic performance parameters of the DSSCs with different photoanode structures. It is obvious in Table 2 that the photoanode with the structure of
$\mathrm{ZnO}$ nanorods decorated $\mathrm{TiO}_{2}$ thin film is more efficient than those with the structures of $\mathrm{TiO}_{2}-\mathrm{ZnO}$ core-shell nanograss [18], $\mathrm{TiO}_{2}$-decorated $\mathrm{ZnO}$ nanorod [19], and composite $\mathrm{ZnO} / \mathrm{TiO}_{2}$ (90/10) [20], although less efficient than the 
TABLE 2: Comparison of the performance parameters of the DSSCs with different photoanode structures.

\begin{tabular}{lccc}
\hline Structure of photoanode & Aspect ratio of $\mathrm{ZnO}$ nanorods & $\eta(\%)$ & Reference \\
\hline $\mathrm{ZnO}$ nanorods decorated $\mathrm{TiO}_{2}$ thin film & 21.3 & 1.30 & This work \\
$\mathrm{TiO}_{2}-\mathrm{ZnO}$ core-shell nanograss & na & 0.62 & {$[18]$} \\
$\mathrm{TiO}_{2}$-decorated $\mathrm{ZnO}$ nanorod & na & 0.93 & {$[19]$} \\
${\mathrm{Composite} \mathrm{ZnO} / \mathrm{TiO}_{2}(90 / 10)}_{\mathrm{ZnO} / \mathrm{TiO}}$ nanonetwork & na & 0.81 & {$[20]$} \\
\hline
\end{tabular}

photoanode with the structure of $\mathrm{ZnO} / \mathrm{TiO}_{2}$ nanonetwork [21].

\section{Conclusion}

By increasing the temperature of hydrothermal reactions from 70 to $100^{\circ} \mathrm{C}$, we have grown vertically aligned $\mathrm{ZnO}$ nanorods onto the $\mathrm{TiO}_{2}$ photoanodes as the blocking layer in DSSCs to reduce the electron back transfer at the $\mathrm{TiO}_{2}$ /electrolyte interfaces. The length of $\mathrm{ZnO}$ nanorods is tunable from 300 to $1600 \mathrm{~nm}$ as the hydrothermal reaction temperature increases from 70 to $100^{\circ} \mathrm{C}$. The length effects of the $\mathrm{ZnO}$ nanorods on the photovoltaic performances of DSSC with the $\mathrm{ZnO}-\mathrm{TiO}_{2}$ photoanode have been investigated. The $J-V$ measurement under the light illumination of $100 \mathrm{~mW} / \mathrm{cm}^{2}$ has demonstrated that the power conversion efficiency of DSSC with the $\mathrm{ZnO}-\mathrm{TiO}_{2}$ photoanode can be increased from $0.27 \%$ to $1.30 \%$ as the length of $\mathrm{ZnO}$ nanorods increases from 300 to $1600 \mathrm{~nm}$. The nearly fourfold enhancement in the efficiency of the $\mathrm{ZnO}$ nanorods decorated DSSCs can be attributed to the larger surface area and the lower defect density in longer $\mathrm{ZnO}$ nanorods. Our results suggest that a high surface area of the nanostructured $\mathrm{ZnO}$ blocking layer is essential to realize highly efficient DSSC because it allows adsorption of sufficiently large number of dye molecules for efficient light harvesting. As a result, the efficiency of $\mathrm{TiO}_{2}$ based DSSC can be effectively enhanced by growing long $\mathrm{ZnO}$ nanorods on the $\mathrm{TiO}_{2}$ photoanode.

\section{Conflicts of Interest}

The authors declare that they have no conflicts of interest.

\section{Acknowledgments}

This work was supported by the Natural Science Foundation of China under Grant nos. 11574036 and 11604028.

\section{References}

[1] B. O'Regan and M. Grätzel, "A low-cost, high-efficiency solar cell based on dye-sensitized colloidal $\mathrm{TiO}_{2}$ films," Nature, vol. 353, pp. 737-740, 1991.

[2] C.-S. Chou, Y.-T. Kuo, J.-W. Jhang, and P. Wu, "Bi-functional lithium doping in dye-sensitized solar cells," Solar Energy, vol. 109, no. 1, pp. 111-117, 2014.

[3] L. Yang, Q.-L. Ma, Y. Cai, and Y. M. Huang, "Enhanced photovoltaic performance of dye sensitized solar cells using one dimensional $\mathrm{ZnO}$ nanorod decorated porous $\mathrm{TiO}_{2}$ film electrode," Applied Surface Science, vol. 292, pp. 297-300, 2014.

[4] Q.-L. Ma and Y. M. Huang, "Improved photovoltaic performance of dye sensitized solar cell by decorating $\mathrm{TiO}_{2}$ photoanode with Li-doped $\mathrm{ZnO}$ nanorods," Materials Letters, vol. 148, pp. 171-173, 2015.

[5] Q. Zhang, C. S. Dandeneau, S. Candelaria et al., "Effects of lithium ions on dye-sensitized $\mathrm{ZnO}$ aggregate solar cells," Chemistry of Materials, vol. 22, no. 8, pp. 2427-2433, 2010.

[6] L. Yang, B.-G. Zhai, Q.-L. Ma, and Y. M. Huang, "Effect of $\mathrm{ZnO}$ decoration on the photovoltaic performance of $\mathrm{TiO}_{2}$ based dye sensitized solar cells," Journal of Alloys and Compounds, vol. 605, pp. 109-112, 2014.

[7] S.-S. Kim, S.-I. Na, and Y.-C. Nah, " $\mathrm{TiO}_{2}$ nanotubes decorated with $\mathrm{ZnO}$ rod-like nanostructures for efficient dye-sensitized solar cells," Electrochimica Acta, vol. 58, pp. 503-509, 2011.

[8] R. Harikisun and H. Desilvestro, "Long-term stability of dye solar cells," Solar Energy, vol. 85, no. 6, pp. 1179-1188, 2011.

[9] H. Choi, C. Nahm, J. Kim et al., "The effect of $\mathrm{TiCl}_{4}$-treated $\mathrm{TiO}_{2}$ compact layer on the performance of dye-sensitized solar cell," Current Applied Physics, vol. 12, no. 3, pp. 737-741, 2012.

[10] R. Liu, W.-D. Yang, L.-S. Qiang, and H.-Y. Liu, "Conveniently fabricated heterojunction $\mathrm{ZnO} / \mathrm{TiO}_{2}$ electrodes using $\mathrm{TiO}_{2}$ nanotube arrays for dye-sensitized solar cells," Journal of Power Sources, vol. 220, pp. 153-159, 2012.

[11] K. M. Lee, E. S. Lee, B. Yoo, and D. H. Shin, "Synthesis of $\mathrm{ZnO}$-decorated $\mathrm{TiO}_{2}$ nanotubes for dye-sensitized solar cells," Electrochimica Acta, vol. 109, pp. 181-186, 2013.

[12] E. Gondek, Y. Djaoued, J. Robichaud et al., "Influence of $\mathrm{TiO}_{2}$ nanoparticles on the photovoltaic efficiency of the ITO/PEDOT:PSS/fluorine copolymers/polythiophene: $\mathrm{TiO}_{2} / \mathrm{Al}$ architecture," Journal of Materials Science: Materials in Electronics, vol. 23, no. 11, pp. 2057-2064, 2012.

[13] M. K. Nazeeruddin, E. Baranoff, and M. Grätzel, "Dyesensitized solar cells: a brief overview," Solar Energy, vol. 85, no. 6, pp. 1172-1178, 2011.

[14] K. Wijeratne and J. Bandara, "Aspect-ratio dependent electron transport and recombination in dye-sensitized solar cells fabricated with one-dimensional $\mathrm{ZnO}$ nanostructures," Electrochimica Acta, vol. 148, no. 1, pp. 302-309, 2014.

[15] Q. L. Ma, R. Xiong, B.-G. Zhai, and Y. M. Huang, "Ultrasonic synthesis of fern-like $\mathrm{ZnO}$ nanoleaves and their enhanced photocatalytic activity," Applied Surface Science, vol. 324, pp. 842-848, 2015.

[16] Y. M. Huang, Q.-L. Ma, and B.-G. Zhai, "A simple method to grow one-dimensional $\mathrm{ZnO}$ nanostructures in air," Materials Letters, vol. 93, pp. 266-268, 2013.

[17] Y. M. Huang, Q.-L. Ma, and B.-G. Zhai, "Controlled morphology of $\mathrm{ZnO}$ nanostructures by adjusting the zinc foil heating temperature in an air-filled box furnace," Materials Chemistry and Physics, vol. 147, no. 3, pp. 788-795, 2014. 
[18] S. A. M. Samsuri, M. Y. A. Rahman, A. A. Umar, and M. M. Salleh, "Effect of $\mathrm{ZnO}$ growth time on the performance of dyesensitized solar cell utilizing $\mathrm{TiO}_{2}-\mathrm{ZnO}$ core-shell nanograss hetero-structure," Materials Letters, vol. 160, pp. 388-391, 2015.

[19] T. Guo, Y. Chen, L. Liu et al., "Enhanced photovoltaic performance of dye-sensitized solar cells using $\mathrm{TiO}_{2}$-decorated $\mathrm{ZnO}$ nanorod arrays grown on zinc foil," Journal of Power Sources, vol. 201, pp. 408-412, 2012.

[20] M. Giannouli, "Nanostructured $\mathrm{ZnO}, \mathrm{TiO}_{2}$, and composite $\mathrm{ZnO} / \mathrm{TiO}_{2}$ films for application in dye-sensitized solar cells," International Journal of Photoenergy, vol. 2013, Article ID 612095, 8 pages, 2013.

[21] A. Vomiero, I. Concina, M. M. Natile et al., " $\mathrm{ZnO} / \mathrm{TiO}_{2}$ nanonetwork as efficient photoanode in excitonic solar cells," Applied Physics Letters, vol. 95, no. 19, Article ID 193104, 2009.

[22] O. Lupan, V. M. Guérin, I. M. Tiginyanu et al., "Well-aligned arrays of vertically oriented $\mathrm{ZnO}$ nanowires electrodeposited on ITO-coated glass and their integration in dye sensitized solar cells," Journal of Photochemistry and Photobiology A: Chemistry, vol. 211, no. 1, pp. 65-73, 2010.

[23] M. D. McCluskey and S. J. Jokela, “Defects in ZnO," Journal of Applied Physics, vol. 106, no. 7, Article ID 071101, 2009.

[24] Y. M. Huang, Q.-L. Ma, and B.-G. Zhai, "Core-shell Zn/ZnO structures with improved photocatalytic properties synthesized by aqueous solution method," Functional Materials Letters, vol. 6, no. 6, Article ID 1350058, 2013.

[25] Q.-L. Ma, R. Xiong, B.-G. Zhai, and Y. M. Huang, "Core-shelled $\mathrm{Zn} / \mathrm{ZnO}$ microspheres synthesised by ultrasonic irradiation for photocatalytic applications," Micro and Nano Letters, vol. 8, no. 9, pp. 491-495, 2013.

[26] X. Wu, G. Lu, and L. Wang, "The effect of photoanode thickness on the performance of dye-sensitized solar cells containing $\mathrm{TiO}_{2}$ nanosheets with exposed reactive $\{001\}$ facets," Journal of Materials Research, vol. 28, no. 3, pp. 475-479, 2013.

[27] S. Ito, T. N. Murakami, P. Comte et al., "Fabrication of thin film dye sensitized solar cells with solar to electric power conversion efficiency over 10\%," Thin Solid Films, vol. 516, no. 14, pp. 46134619, 2008. 

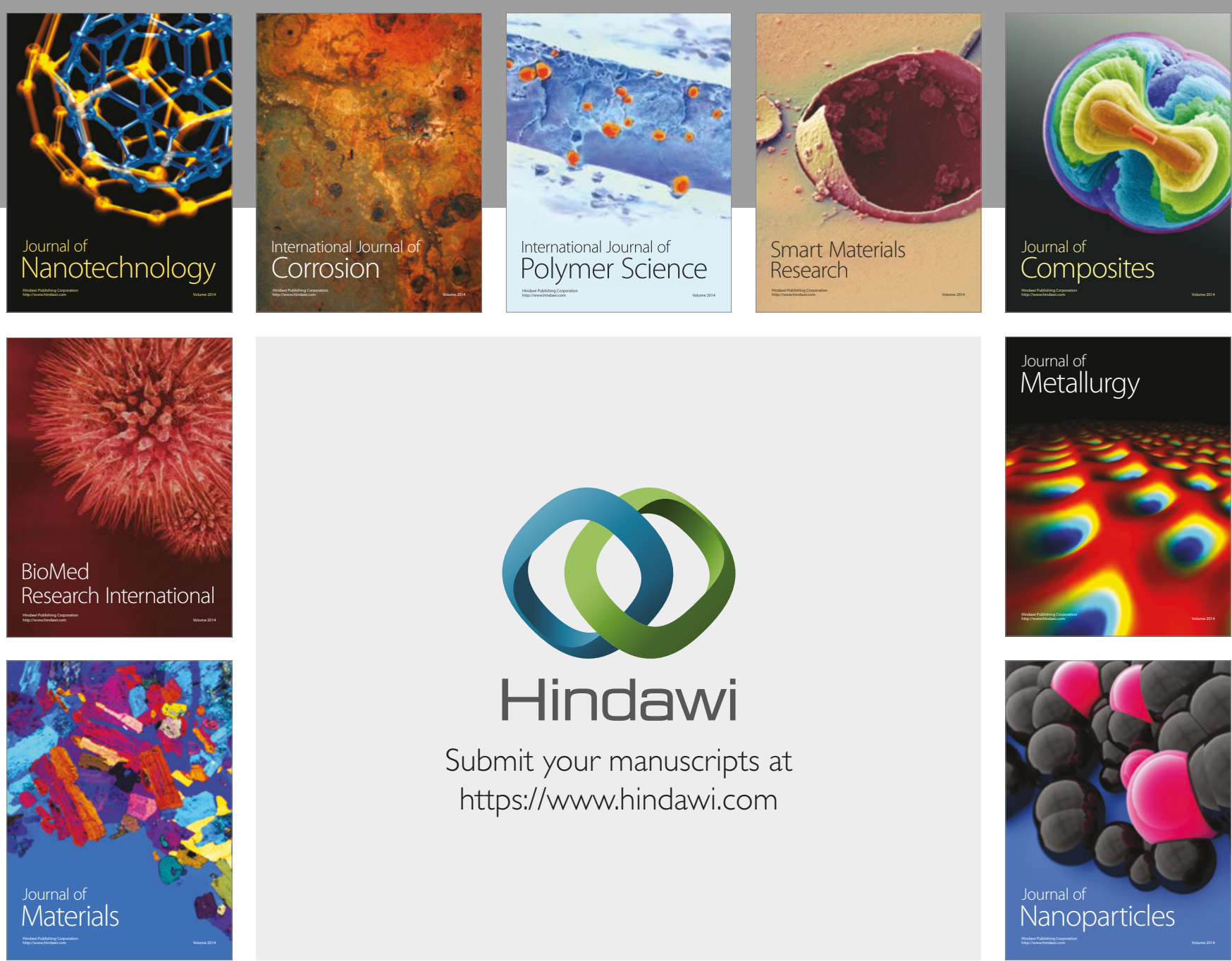

\section{Hindawi}

Submit your manuscripts at

https://www.hindawi.com
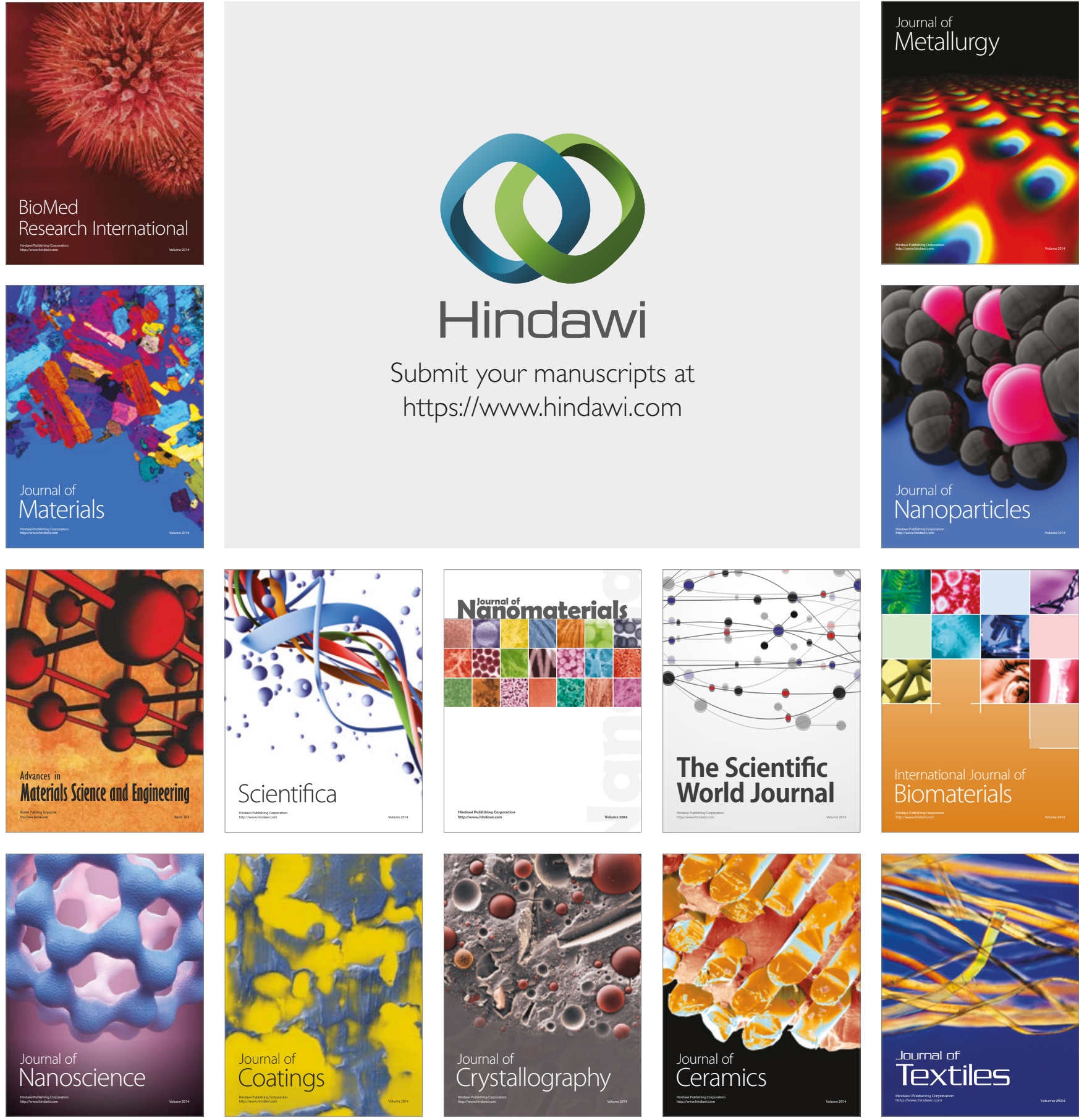

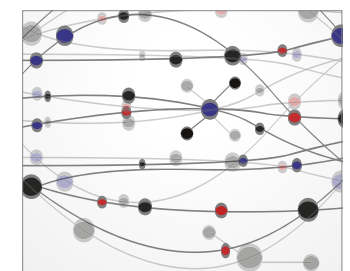

The Scientific World Journal
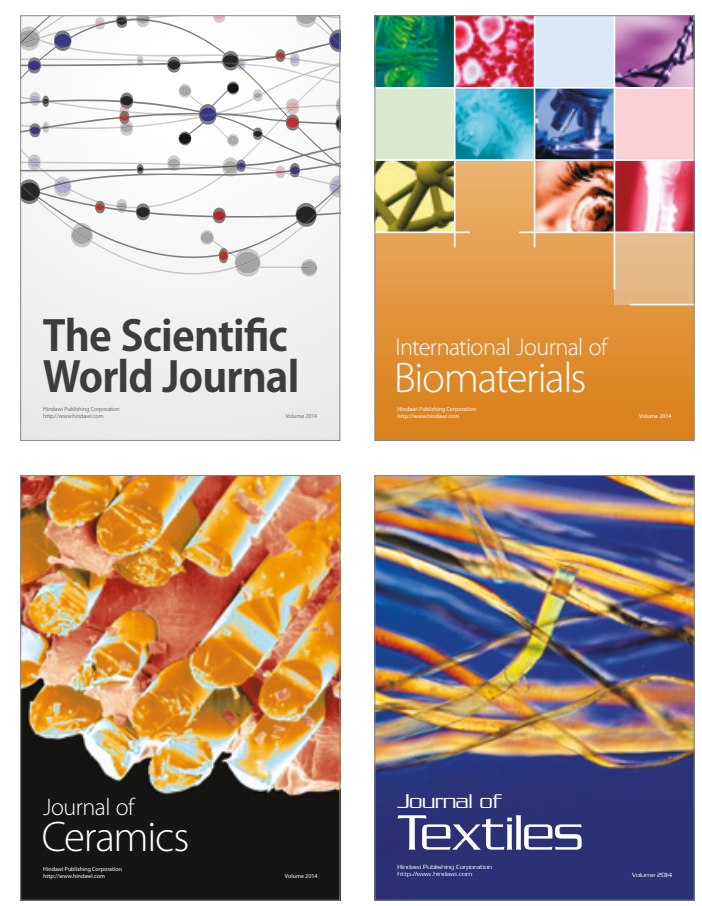